\title{
Becoming more European after ERASMUS? The Impact of the ERASMUS Programme on Political and Cultural Identity
}

Karina Oborune

\begin{abstract}
The European Commission and scholars emphasize that the ERASMUS programme is a successful example of European integration and a symbol of construction of European identity. But because of the lack of empirical findings, this paper has been devoted to research of the impact of the ERASMUS programme on fostering European identity. The quantitative survey of 330 former, potential and non-ERASMUS students provides partly justification that the ERASMUS Programme has impact on promoting European identity. This study was implemented for the first time in [name deleted to maintain the integrity of the review process], but the results are important not only in [name deleted to maintain the integrity of the review process], but also at the EU level. EU officials should take into consideration the fact that potential ERASMUS students already have greater European self-identification than non-mobile students, therefore the European identity should be promoted in those students who do not take participation in.
\end{abstract}

Keywords: ERASMUS Programme, Mobility, European Identity, European Integration, European Union

\footnotetext{
Corresponding author: Karina Oborune, $\mathrm{PhD}$ Candidate, University of Latvia, E-mail: Oborune.Karina@gmail.com
} 
"Bringing students to Europe, bringing Europe to students..."

\section{Introduction}

Motto of the ERASMUS Programme

Today the ERASMUS Programme is described as one of the symbols of the construction of European identity. Moreover, the promotion of European identity contributes to promotion of sociopolitical aspects of European integration. Furthermore, strong European identity has impact on believe in EU project and therefore fosters the further economic integration. On the other hand, there is a vicious circle because also growing economic integration will have impact on creating much stronger European identity. The idea of studying the effect of student mobility on European integration was initiated by Lijphart (Lijphart, 1964, 252) but never implemented. Also nowadays several authors (e.g. Wallace, Jacobs \& Maier, Kamphausen, Valentini, Green, Fligstein, Chopin) point to the ERASMUS programmme as a tool for promoting European identity. But, unfortunately, there is a limited number of empirical studies done in this field. Nevertheless, the emergence of research on the ERASMUS programme in the last years shows the recent interest in studying this field. Corradi (2006) has analyzed the ERASMUS programme in the historical perspective, Sauzet (2008) has focused on the pedagogical evaluation of intercultural learning and stereotypes. Van Mol (2009a, 2009b) and Sigalas (2006, 2009) have researched empirically the impact of the ERASMUS Programme on the European identity. Sigalas has studied British students who have and who have not participated in the ERASMUS programme, as well students who have studied as ERASMUS students in UK. Contrarily, Van Mol has studied non-mobile, potential mobile, future mobile and mobile students in sixteen European countries.

Interestingly, Sigalas came to the conclusion that although it is "widely assumed it plays a pivotal role in the promotion of a European identity", the programme "does not foster a European self-identity or a sense of European pride”. (Sigalas 2009, 1) Both Sigalas (2009) and Van Mol (2009b) conclude that European identity feeling is already present before participation in the programme. Therefore, I have proposed following statement: the ERASMUS Programme does not have an impact on promotion of European identity. The objective of the present paper is 
to analyze the European self-identification of students of [name deleted to maintain the integrity of the review process] who have participated/have applied/have not participated in the ERASMUS Programme. To achieve this objective, the following tasks have been drafted: first, to operationalize concept of "European identity"; second, to develop appropriate methodology; third, to conduct a survey of students of [name deleted to maintain the integrity of the review process]. In the empirical part I have taken into account the limitations of methodological frameworks of previous research. For example, Sigalas points to three studies about the ERASMUS Programme as promoter of European identity done by Stroebe et al. (1988), Krämer-Byrne (2002) and King \& Ruiz-Gelices (2003) but to Sigalas's mind all these researches suffer from some methodological limitations - either unrepresentative sample, or use retrospective rather than longitudinal assessment, or there were studied only ERASMUS students and they were not compared with nonERASMUS students. In this research a quantitative survey of nonmobile, potential-future mobile students (treatment group) and mobile students (control group) was conducted.

\section{Literature Review}

Before analyzing the concept of "European identity" I should specify what I mean by concept of "identity". However, defining and studying "identity" is a difficult task to accomplish. The three main approaches of theorizing the concept of "identity" are following: 1) universalistic (structural) (Habermas); 2) sociological (e.g. Easton, Nisbet, Weber, Giddens) and 3) social-psychological approach (e.g. Turner, Tajfel, Oakes). There is also a distinction between 1) social identity (Tajfel, Williams), 2) cultural identity (Clifford, Hall) and 3) collective identity (Geertz, Habermas). However, this distinction is debatable and there are different opinions among scholars. For instance, Loukola points out that sociologists distinguish between social, cultural and personal (instead of collective) identity (Loukola 2005, 113), but Snow argues that there is social, personal and collective identity (Snow 2001, 1). From the other side, Fearon claims that there is only a distinction between social and personal identity (Fearon 1999, 2.) 
Furthermore, Heikinnen thinks that cultural identity is one of the forms of social identity (Heikinnen 2009, 29). Thus, identity is a multidimensional concept and dynamic social phenomenon. The definition of identity I prefer: identity is a feeling of belonging to a specific category determined by common characteristics and recognized by other members. Despite the fact that there are different approaches of theorizing concept of "identity", for the purpose of this paper I prefer distinction between individual and collective identity because this distinction is mainly used in the debate about European identity (Müller 2007, 102). In the case of European identity we speak about collective and not about individual identity. Moreover, European identity is part of multiple identities that one can have. I would rather agree with scholars who argue that European identity is collective identity (Hollmann 2009, 48; Delanty 2003).

In contrast, if we talk about European identity, then the main debate among scholars is not about European identity as social, cultural, personal or collective identity but rather if European identity is individual or collective identity (Müller 2007, 102). I would rather agree with scholars who argue that European identity is collective identity (Hollmann 2009, 48; Delanty, 2003). To justify my opinion, at first, I will elaborate on the main differences between individual and collective identity and then I will analyze the definitions of concept of "identity". Weeks proposes such definition of individual identity ("Me-feeling"): "what you have in common with some people and what differentiates you from others" (Weeks 1990, 88). Tajfel defines individual identity in the following way: "part of the individual's self-concept which derives from knowledge of membership of a social group/s together with the value and emotional significance attached to that membership" (Tajfel 1981, 255).

Collective identity requires interaction between individuals ("Wefeeling"). Valentini provides following definition: "a feeling and belief that one belongs to a specific category determined by common characteristics", and this feeling and belief should be recognized by other members (Valentini 2005, 5). Furthemore, I would like to emphasize that collective identity can be analyzed as active or passive element (Baki 2009, 5). Collective identity as an active element means that we study 
how does identity as a political tool affect European integration. A passive element means that we study how does identity as a social process change European integration. The ERASMUS programme is both a political tool and a social process therefore in this research both active and passive elements are studied.

There is a vast amount of definitions of the concept of identity. In this part I would like to emphasize one concrete definition. Žagar provides a definition of "identity" which combines elements of individual and collective identity. Žagar' $\mathrm{s}$ definition is the following: "identity is the feeling of belonging to a certain entity, defined by different (in the case of collective identities - agreed upon and shared) objective and subjective criteria”. (Žagar 2001, 2-3) Moreover, as Žagar and other scholars have emphasized, identity (either individual or collective) is not fixed, but can change and transform (Žagar 2001, 3; Valentini 2005, 9). Therefore, identity is a social phenomenon that can be in the process of formation rather than static. Thus identity is a dynamic phenomenon. Moreover, identity is a multidimensional concept and I do agree with scholars that multiple identities do exist (Risse 2004; Huyst 2008; Caporaso \& Kim 2009). European identity can be part of such multiple identities together with national identity.

From this discussion of the concept of "identity" I would like to emphasize four aspects. First, despite the fact that there are different approaches of theorizing concept of "identity", for the purpose of this thesis I prefer distinction between individual and collective identity because this distinction is mainly used in the debate about European identity. Second aspect I would like to emphasize is that in the case of European identity we speak about collective and not about individual identity. Moreover, European identity is part of multiple identities that one can have. Third, identity is a dynamic social phenomenon that can change. Last but not least, the definition of identity I prefer: identity is a feeling of belonging to a specific category determined by common characteristics and recognized by other members. This definition reflects the "collectivity" element that is prescribed to the European identity.

There is a vast amount of literature on the issue of European identity and in the past decades it has become one of the most 
researchable and highly debatable topics. "Additionally, in the new member countries the very notion of European identity seems to be more widely discussed than in the old member states" (Valentini 2005, 10). Historians, political scientists, sociologists and social psychologists have studied concept of European identity, thus it has become an interdisciplinary field to observe. However, to my mind, because of the latter there are shortcomings in the literature - a lack of in-depth theoretical and empirical analysis taking into account many dimensions and perspectives of this phenomenon. I agree with Huyst's argumentation why studying the European identity is a comprehensive task: it is hard to define European identity and to measure it (Huyst forthcoming, 6; Herrmann \& Brewer 2004). Indeed, defining the concept of European identity is a tough task. Even nowadays there is a debate if European identity does exist (see Kielmansegg 1996; Offe 1998). However, I would argue that the European identity exists and there are scholars who agree with that.

Another failure is that some scholars associate "Europe with European Union (..) which is reflected also in the general definition of the word "European"” (Valentini 2005, 4). Therefore I agree with Rollis that each of the words in the concept of "European identity" taken individually may be ambiguous (Rollis 2005, 163). Moreover, I disagree with Fokion et al. that "European identity tends to be meaningful only when it is contrasted against anything considered as non-European" (Fokion et al. 2006, 8) because this argument rather separates

"European" and "identity" but does not take into account the specific meaning of these words

together.

Van Mol points to two approaches for the study of European identity: 1) top-down; and 2) bottom-up approach (Van Mol 2009a, 9). Top-down approach focuses on what unifies Europeans (e.g. cultural heritage, values) (Bruter 2005, 5). Bottom-up approach focuses on feelings of Europeans toward Europe. Similarly as Van Mol, also in this study will be used 
bottom-up approach: the influence of the ERASMUS Programme on individual's European

identity feeling. Taking into account the discussion of the concept of "identity", I would agree with Castells that European identity is the set of values and feeling of belonging to a distinctive European entity, for example, European culture (Castells 2000, 3). However, there are scholars who conclude that European identity is an elite project (Bancks 2007, 12; Guibernau 2001, 27). Furthermore, Fuchs argues that "for a further emergence of European identity a stronger political integration of the EU is necessary". (Fuchs 2006, 18)

Nevertheless, we agree with this opinion or not, I share my point of view with academians who conclude that the creation of European identity is still an ongoing, very difficult, complex and time consuming process (Öner 2004, 35; Bakke 1995; 26; Jasson 2001, 157). Kohli distinguishes four levels of analysis of European identity: 1) constitutional 1;2) discursive (political); 3) cultural; 4) individual (Kohli 2000; 120). Scholars (e.g. Niedermayer and Sinnot, McLaren, Green, Fligstein) and also Eurobarometer use the selfidentification - it could be all levels of analysis of European identity except the first. However, I would agree with Madeker that Kohli's fourth level of analysis - "individual's feelings of belonging to Europe as a social or political entity" - is the interest of scholars in the most cases (Madeker 2006; 3).

On the other hand, according to Bruter we can distinguish between political and cultural European identity. Both identities are important for the thesis because the political European identity implies that an individual identifies him/herself with the European Union, but the cultural European identity implies that individual "shares a certain common culture, social similarities, ethics, values and religion." (Bruter 2004, 2005, 2008, 279) Interestingly, based on qualitative interviews in Belgium and Spain, Van Mol concludes that students who have participated in the ERASMUS programme refer to cultural European identity, but students who have not taken part in - to political European identity (Van Mol 2009a, 10). On the contrary, Mondrasse has emphasized that only common cultural European identity does exist (Buzaianu 2006, 78). 
There are three different opinions about the relationship between European and national identity. First point of view is that European and national identity are competing (Fuchs et al. 2009). Therefore some scholars see a strong national identity as the main reason for a week European identity but, on the other hand, there are academians (e.g. Eisenstadt \& Giesen 1995; Risse 2004) who argue that "the relationship between the two forms of identification is mutually exclusive" (Kaelble 2009, 207). Second view is that European and national identities are complementary. For instance, Fossum, Grundy and Jamieson argue that one can have both national and European identity (Fossum 2001, 375376; Grundy \& Jamieson 2007). Also other political scientists emphasize that European identity cannot substitute national identity (Laffan 2008, 98-99; Prisacariu 2007, 5; Järve 2005, 34). Moreover, the project of European identity does not mean the loss of national identity (Müller 2007, 107). Additionally, Hedetoft (1994, 19) and Sedláček (2009) conclude that people who feel a strong European identity could also feel a 11 strong sense of national identity. This conclusion was also drawn by King and Ruiz-Gelices (2003, 247).

The last point of view is that on one hand national and European identity can be seen as complementary but on the other hand contradictory (Öner, 2004, 34). This is similar argument brought by Smith who distinguishes two levels of debate: at the practical and at the conceptual level (Smith 1992, 56). He argues that European and national identity are competing with each other at the practical rather than conceptual level. I rather disagree with Smith because to my mind these identities are not competing but rather can exist complementary both on the conceptual and practical level. Therefore taking into consideration the analysis of the concept of "European identity" above I would like to point to five viewpoints. First, to my mind European identity does exist. However, it is a tough task to study and measure European identity. Second, European identity is a feeling of belonging to a distinctive European culture (cultural European identity) and/or European Union (political European identity). Third, bottom-up approach will be used in this research. Fourth, to my mind European and national identities are 
complementary. Finally, the formation of European identity is a complex project to accomplish.

\section{Methodological Framework}

Green (2007), Moes (2008), and Huyst (forthcoming) conclude that quantitative approach is more often used to study European identity, especially using the data of Eurobarometer. But Eurobarometer has both advantages and limitations. On one hand, it allows generalizing data, on the other hand, there is criticism of the measurement used in Eurobarometer (Sinnot 2005; Bruter 2008). Moreover, questions on European identity are rather questions concerning attachment (to Bruter's mind attachment is not the same as identity (Bruter 2008 in Huyst forthcoming, 10)) and most questions neglect the fact that people can have multiple identities, for example, Bruter argues that national and European identity is in tension in Eurobarometer questions (Bruter 2008 in Huyst forthcoming, 10). Furthermore, Cerutti and Lucarelli (2008) and Bruter (2008) recommend using not only a quantitative but also a qualitative approach in the study of the European identity. There are both advantages and limitations in using the two approaches together. For example, Cropley points to the main weakness of the qualitative research method: it gives far less emphasis to the idea of causation (Cropley 2002, 10). At first, I have considered using both approaches, but for this research it is enough to use survey, especially because of time limit.

The population - students of [name deleted to maintain the integrity of the review process] who have not participated/have applied to participate/have participated in the ERASMUS programme (2009/2010). Sample size: 100 non-mobile, 100 future mobile, and 100 mobile students. A questionnaire was sent to the 1) non-mobile students, 2) future mobile students (who would participate in the ERASMUS programme in the autumn term of the academic year of 2010/2011) and 3) mobile students (students who have participated in the ERASMUS programme in the academic year of 2009/2010). The questionnaire was distributed via e-mail list with the help of BA, MA and $\mathrm{PhD}$ coordinators of the ERASMUS programme of universities of [name deleted to 
maintain the integrity of the review process]. I have used simple random sampling in my survey.

Online survey (http://erasmusaptauja.questionpro.com) was conducted in May of 2010.

I have constructed indexes based on the proposed index by the Baltic Institute of Social Sciences in the research "Ethnic tolerance and Integration of the [name deleted to maintain the integrity of the review process]n Society" (2004). I have also taken into account other research studies about the influence of the programme on European identity. I have created following two indexes:

(1) The multicultural background index

$H_{0}$ : ERASMUS [former and future] students are more

multicultural than non-ERASMUS students

$H_{1}$ : ERASMUS [former and future] students are same multicultural as non-ERASMUS students

- I have a good knowledge of at least one foreign language (e.g. English, German, French, Spanish, Italian etc.)

- I have participated in exchange, workshop, conference or similar international events abroad

- I have lived abroad for more than one month (except the ERASMUS programme)

- I have friends from another culture (or nationality, or ethnic minority)

- There are different cultures (nationalities, ethnic minorities) in my family

(2) The European identity index $H_{0}$ : ERASMUS [former and future] students feel more European than non-ERASMUS students

$H_{1}$ : ERASMUS [former and future] students feel same European as non-ERASMUS students

- I feel European

- I am proud of being European

- In the near future I see myself as European

- I can trust Europeans

- I feel close to Europeans

- [name deleted to maintain the integrity of the review process]'s EU membership is a good thing 
- European unification is a good thing

\section{Analysis of Survey}

Results reveal that non-mobile students have a similar desire to uphold a national identity to that of mobile students and future mobile students. Similarly to Sigalas's survey results former and future ERASMUS students fare much better in the field of foreign languages than non-mobile students (2006: 20). If we compare future and mobile students, we can see there is no difference because $95 \%$ of mobile and $94 \%$ of future mobile versus $83 \%$ of non-mobile students have agreed that they have a good knowledge in at least one foreign language (e.g. English, German, French, Spanish, Italian etc.). Moreover, speaking more than one European language is indispensable for "learning about the particular foreign culture which is also instrumental in the formation of a common European identity" (Sigalas 2009, 11). Consequently, those who apply for exchange programmes already have a good knowledge of foreign languages. On the other hand, this is an obstacle for nonERASMUS students. Students could also be affected by previous international exchange. I can draw conclusion that there is a huge difference between future mobile and non-mobile students and, thus, previous exchange or living abroad experience can promote a student's interest in application for the programme. Also Murphy-Lejeune's conclusion is proven that previous experience in a foreign country or culture influences the decision to participate in the programme. If we look at the conclusions drawn above about knowledge of foreign languages, previous international exchange experience and the experience of living abroad, then Fligstein is right that people who speak foreign languages, have traveled and lived in other European countries, tend to adopt more European identity and think of themselves as Europeans more than those who have not $(2009,133)$. Mobile and future mobile students had more previous experience of international exchanges and living or studying abroad than non-mobile students.

Mobile and future mobile see themselves as more European than non-mobile students. Interestingly, mobile students identify themselves more as Europeans and also have more national identity than non-mobile 
students. Hedetoft, Sedláček, King and Ruiz-Gelices are right concluding that people who feel a strong European identity could also feel a strong sense of national identity. Furthermore, it means that the ERASMUS programme does not mean the loss of national identity. Moreover, the argument discussed in the conceptual part is proven: people can have both strong European and national identity and these identities are complementary rather than excluding each other. The results of the component of "political European identity" prove Kaelble's statement that the programme reinforces loyalty to Europe $(2009,209)$. But, on the other hand, it also approves Papatsiba's argument that "the analysis of the observations at the end of the exchange period does not reveal a strong European identity" $(2004,6)$. This could be explained by the fact that the Erasmus students already have European identity before participating in the exchange programme and exchange students differ from non-mobile students (for example, mobile students have more multicultural background etc.). On the other hand, Erasmus programme adds the loyalty to EU as a political organization. If we look at the responses of "community feeling" in detail, then results also are similar to responses of trusting people from different nationalities where non-mobile students trusted less people from other cultures than mobile and future mobile students. Results also prove Sigalas's conclusion that socialising with other people promotes a feeling of community $(2006,23)$ because mobile students trust and feel close to Europeans more than future mobile students. As Sigalas adds "the more people socialise with each other the more they trust each other and the closer they feel" (Ibid). The last two statements divide into euro-sceptics vs. euro-optimists (Sigalas 2006, 2425) depending on if students agree or disagree with the following two statements: [name deleted to maintain the integrity of the review process]'s EU membership is a good thing; European unification is a good thing. There is more euro-scepticism in the group of non-mobile students than mobile and future-mobile students. There are more eurooptimists among mobile students than non-mobile students. Moreover, we should take into account Fligstein's conclusion that "if a person has some European identity, he/she is more likely to see Europe as a good thing for his/her country" (2009, 150). Holmes (2000) is right arguing 
that those who have not interacted with people from other European countries are less favorable towards the European integration.

\section{Discussion}

On one hand, future mobile students are different from nonmobile students and therefore have already more European selfidentification. But on the other hand, mobile students have more European identity than future mobile students; therefore the programme has an effect on European identity, which could be the result of communication with other Europeans during exchanges. Furthermore, from these results I would draw the following conclusion: rather nonmobile students than future mobile students would require more intercultural experience and promotion of European identity, because future mobile students already have European identity.

Nevertheless, the programme plays an important role in promoting the idea that we, Europeans, are all alike and foster trust and feel closer to Europeans. Moreover, the Programme has also an impact on the society, which interacts with ERASMUS students (both the host country during the ERASMUS exchange and the home country when mobile students accomplish the programme). Moreover, exchange students can have an impact on the society they belong to. European identity should be promoted in non-mobile students, therefore exchange of information about Erasmus programme is essential. When ERASMUS students return from the exchange programme, they become ambassadors of European integration and European identity (Papatsiba 2005, 5-6; Wallström 2007, 4). However, the current number of European students who take participation in the Erasmus programme (one per cent) is too low to promote European identity.

\section{Conclusion and Recommendations}

First, the major conclusion of the paper is the following: on one hand, ERASMUS programme influences students' European identity, but on the other hand, students who take part differ from non-mobile students -have more multicultural background, stronger national and European identity. The programme is a catalyst rather than promoter because future 
mobile students already self-identify with Europe more than non-mobile students do. From the analysis of the survey results we can draw the conclusion that good knowledge of foreign languages, previous international exchange experience and multicultural background on the one hand is a potential obstacle for non-mobile students to participate in the programme, on the other hand, these could be pre-conditions for adopting a European identity.

Indeed, the programme is both a political tool and a social process. Former and future ERASMUS students adopt more political European identity and community feeling than non-ERASMUS students contrary to previous research studies (Sigalas 2006, 2009; Van Mol 2009b). After exchange programme students become more loyal to EU. But on the other hand, Van Mol is right arguing that the programme acts as a catalyst for European identity because feeling of European identity is already present in students before exchange (2009b). Moreover, it does not mean that if someone has a strong national identity he/she cannot have strong European identity. The survey data show that ERASMUS students have both strong national and European identity. It is often argued that the programme fosters European identity. On the other hand, there is a limited number of studies which analyze these aspects. Besides, there have been previous research studies only in the case of Britain (Sigalas 2006, 2009) and on the aggregate level in sixteen countries (Van Mol 2009b). Therefore, this case study of students of [name deleted to maintain the integrity of the review process] using the bottom-up approach and the theoretical framework developed can contribute to and supplement studies done in other European countries. It is noteworthy that this study has disproven some of the statements made by previous studies. For example, the survey results have revealed that Sigalas (2006) does not seem to be right arguing that the programme does not have an impact on political European identity and has a small effect on promoting support for European integration. Furthermore, Sigalas's conclusion that the ERASMUS students are not necessarily more multicultural and 'Euro-friendly' than other students also contradicts the results of the survey. 
Next, potential further implications of this paper are provided. First, using the methodology I have developed there can be similar studies implemented in other European countries. Second, the results of the survey are important not only for [name deleted to maintain the integrity of the review process], but also for the European Community. Especially EU officials should take into account that those students who participate in the programme already feel more European than nonmobile students. The main limitation of this study is the lack of longitudinal assessment. Another limitation is the lack of comparison with incoming students because it could be as in the case study of Britain (Sigalas 2006) that the host country plays a crucial role. The third limitation to emphasize is a lack of qualitative research because the interviews with students would reveal more information about the preconditions for formation of European identity. 


\section{References}

Bakke, E. 1995. Towards a European Identity? Arena Working Paper 10/1995 http://folk.uio.no/stveb1/Towards_a_European_Identity.pdf

Bancks, K.A. 2007. "National Identity and Its Affect on Policy Creation: In the Context of Hungary and Romania". MA Paper, Central European University.

Bruter, M. 2004. “On What Citizens Mean by Feeling 'European': Perceptions of News, Symbols and Borderless-ness". Journal of Ethnic and Migration Studies, 30(1): 21-39.

Bruter, M. 2005. Citizens of Europe? The Emergence of a Mass European Identity.

Houndmills, Basingstoke, Hampshire \& New York: Palgrave MacMillan.

Bruter, M. 2008. Legitimacy, Euroscepticism \& Identity in the European Union - Problems of Measurement, Modelling \& Paradoxical Patterns of Influence, Journal of Contemporary European Research, 4 (4): 273285.

Buggert, S. \& Preller, K. 2008. "European Identity as a Multilevel Construct. Which Factors Influence Support For the European Union and European Identity?" www.unikonstanz.de/.../european_identity_buggert.preller.pdf

Caporaso, J.A. \& Kim. M. 2009. The dual nature of European identity: subjective awareness and coherence, Journal of European Public Policy, 16 (1): 19-42.

Castells, M. 2000. "The Construction of European Identity" Statement Prepared for the European Presidency of the European Union. http://chet.org.za/webfm_send/327

Chopin, T. 2008. "Complex Relationships between European mobility and Identity"

Report "Promoting Youth Mobility in Europe" Paris, 12.09.2008 www.strategie.gouv.fr/IMG/pdf/Appendice4Version_F_.pdf

Cerutti, F. \& Lucarelli, S. 2008. The Search for a European Identity: Values, Policies and Legitimacy of the European Union. New York: Routledge.

Corradi, S. 2006. "Erasmus Programme: The origin, preparatory years (1963 1986) and foundation of the EU initiative for the exchange of university students, reported and documented by the scholar who first conceived of it". Life Learning Laboratory, http://www.lifelong.it/library/erasmus_en.doc 
Delanty, G. 2003. "Is there European Identity?" Global Dialogue, Volume 5, No 3-4 Summer/Autumn 2003, The Future of Europe http://www.worlddialogue.org/content.php?id=269

Fearon, J. D. 1999. "What is Identity (As We Now Use the Word)"? Stanford University http://www.stanford.edu/ jfearon/papers/iden1v2.pdf

Figel, J. (Education and Culture DG). 2006. LLP ERASMUS Success stories Europe creates opportunities. Luxembourg.

http://ec.europa.eu/dgs/education_culture/publ/pdf/erasmus/successstories_en.pdf

Fligstein, N. 2008. The EU, European identity, and the future of Europe. Oxford: Oxford University Press.

Fligstein, N. 2009. "Who are the Europeans and how does this matter for politics?" in Checkel, Jeffrey T.; Katzenstein, Peter J. European Identity. Cambridge University Press.

Fokion, G. \& Apostolos, Z. \& Ioannis, E. 2006. "Europeaness" and "Otherness": Identity and Diversity within EU and its Education. Paper presented at the $10^{\text {th }}$ International Conference of the International Society for the Study of European Ideas and the University of Malta. www.iaie.org/athens/download/multigreece_europaness_otherness.doc

Fossum, J. E. 2001. "Identity Politics in the European Union". Journal of European Integration, Vol. 23, Issue 4: 373-406

http://www.informaworld.com/smpp/content $\sim$ content=a788531690\&db $=$ all

Fuchs, D. \& Schlenker, A. 2006. "European Identity and the Legitimacy of the EU". Conference "Democracy, Legitimacy and Identities: Citizens on the Construction of Europe" in Lodz

http://www.euconsent.net/library/brx061012/Klingemann_Lodz0603.pdf

Fuchs, D. \& Guinaudeau, I. \& Schubert, S. 2009. National Identity, European Identity and Euroscepticism. In Fuchs, Dieter; Magni-Berton, Raul; Roger, Antoin (eds.), Euroscepticism. Images of Europe among mass publics and political elites. Opladen \& Farmington Hills: Barbara Budrich Publishers.

Green, D. M. 2007. The Europeans. Political Identity in an Emerging Polity. London: Lynne Rienner Publishers, Inc.

Grundy, S. \& Jamieson, L. 2007. European Identities: From Absent-minded Citizens to Passionate Europeans. Sociology (Journal of the British Sociological Association), 41(4): 663-680. 
Guibernau, M. 2001. "Introduction: Unity and Diversity in Europe" in Guibernau, M. (ed.) Governing European Diversity. London: Sage Pub. Hansen, H. M. 1993. Sample Survey Methods and Theory, Vol.1, Wiley.

Hedetoft, U. 1994. "National identities and European integration "from below": bringing people back in", Journal of European Integration 18(1).

Heikinnen, M. 2009. "Estonianianism in a Finnish Organization. Essays on Culture, Identity and Otherness". University of Oulu. http://herkules.oulu.fi/isbn9789514292163/isbn9789514292163.pdf

Herrmann, R. K. \& Brewer, M. B. 2004. Identities and Institutions: Becoming European in the EU. In Herrmann, Richard K.; Risse, Thomas; Brewer, Marilynn B. (eds.) Transnational Identities. Becoming European in the EU: 1-22. Lanham, Boulder, New York, Toronto; Oxford: Rowman; Littlefield Publishers, Inc.

Hollmann, L. 2009. "European Identity. Conditions for a European Political Identity". Blekinge Institute of Technology. European Spatial Planning and Regional Development. http://www.bth.se/fou/cuppsats.nsf/all/fcfdc89991597261c12575e30067 d760/\$file/ESP_Paper_Hollmann_Final.pdf

Huyst, P. 2008. "We Have Made Europe, Now We Have to Make Europeans" Researching European Identity Among Flemish Youths. Journal of Contemporary European Research (JCER), 4 (4): 286-302

Huyst, P. Forthcoming. The Europeans of Tomorrow. Researching European Identity Among Young Europeans. Centre for EU - studies. Ghent University. http://www.unc.edu/euce/eusa2009/papers/huyst_04D.pdf

Jacobs, D.; Maier, R. 1998. European Identity: Construct, Fact and Fiction. Utrecht University in Gastelaars, M. \& de Ruijter, A. (eds.) A United Europe. The Quest for a Multifaceted identity. Maastricht: Shaker: 1334.

Jasson, C. 2001. The Challenge of European Identity. Refugee Survey Quarterly, Vol. 20, No. 2

Järve, P. 2005. "Identity Change in Baltics: EU-zation, Diversification, or Both?” in Ozoliņa, Žaneta (ed.) Changing, Overlapping and Interacting Identities Scientific Papers. University of [name deleted to maintain the integrity of the review process]. Vol. 680.

Kaelble, H. 2009. "Identification with Europe and politicization of the EU since the 1980s" in Checkel, Jeffrey T.; Katzenstein, Peter J. European Identity. Cambridge University Press. 
Kalanowska, E. 2008. "10 years of the ERASMUS Programme in Poland (1998-2008)" Foundation for the Development of the Education System, Polish National Agency for the Lifelong Learning Programme http://www.erasmus.org.pl/s/p/artykuly/29/294/10 lat erasmusa ang i nternet.pdf

Kamphausen, G. 2006. European integration and European Identity: Towards a Politics of Differences? International Issues \& Slovak Foreign Policy, Issue 1: 24-31

Kielmansegg, G. P. (1996), Integration und Demokratie. In Jachtenfuchs, Markus/Kohler-Koch, Beate. (Hrsg): Europäische Integration. Opladen: Leske Budrich: 47-71

King, R. \& Ruiz-Gelices, E. 2003. International student migration and the European 'year abroad': effects on European identity and subsequent migration behaviour. International Journal of Population Geography 9: 229-52.

http://sgo.pccu.edu.tw/GEOG/CHI/D/D1/D1A/D1A/D1A-1/19B-international.pdf

Kohli, M. 2000. "The Battlegrounds of European Identity". European Societies 2 (2), 113-137.

Krämer-Byrne, S. 2002. The experience of female ERASMUS students in higher education. M.Phil. diss., Department of Education, University of Birmingham.

Laffan, B. (2008), "The politics of Identity and Political Order in Europe". Journal of Common Market Studies. Vol. 34, Issue 1: 81-102.

Lijphart, A. 1964. "Tourist traffic and integration potential". Journal of Common Market Studies 2: 251-261

Loukola, O. 2005. "The Concept of Collective Identity and Liberal Theory" in Ozoliņa, Žaneta (ed.) Changing, Overlapping and Interacting Identities Scientific Papers. University of [name deleted to maintain the integrity of the review process]. Vol. 680.

Madeker, E. 2006. "Turkey - a part of Europe? The Construction of European Identity in the German Enlargement". Debate Paper prepared for the ECPR. Bilgi University Istanbul, 21-23 September 2006 http://www.jhubc.it/ecpr-istanbul/virtualpaperroom/049.pdf

McLaren, L. 2006. Identity, interests and attitudes to European integration. Basingstoke: Palgrave-Macmillan.

Ministry of Education and Science of Republic of [name deleted to maintain the integrity of the review process]. 2009. Report of Higher Education of 
[name deleted to maintain the integrity of the review process] in 2009 (numbers, facts, tendencies) http://izm.izm.gov.lv/registristatistika/statistika-augstaka/parskats-2009.html

Moes, J. 2008. "European identity compared. A mixed methods approach." Paper presented at the ECPR Fourth Pan-European Conference on EUPolitics, Riga, [name deleted to maintain the integrity of the review process], 25-27 September 2008.

Murphy-Lejeune, E. 2002. Student Mobility and Narrative in Europe. The new strangers. London \& New York: Routledge.

Müller, K. B. 2007. "Search for a European Identity - Psycho-Sociological Perspective (An Attempt at Agency Approach)". Central European Journal of International and Security Studies, Vol 1., Issue 1 http://www.cejiss.org/assets/pdf/articles/vol1-

1/Karel_B_Muller_Search_for_a_European_Identity\%E2\%80\%93Psyc ho-Sociological_Perspective.pdf

New Europe. 2008. "Higher education celebrates 21 years of mobility, cooperation" 19.05.2008. http://www.neurope.eu/articles/86836.php

Öner, S. 2004. The Limits of European Integration: The Question of European Identity. Anakra Avrupa Calismalari Dergisi. Cilt: 3 No: 2: 27-38

Papatsiba, V. 2004. “"Erasmus” Mobility: students in the European adventure” International Association of universities. Newsletter. January-February 2004. Vol. 10, No1-2 http://www.iau-aiu.net/newsletters/iaunew10-1-2en.pdf

Papatsiba, V. 2005. "Student Mobility in Europe: An Academic, Cultural and Mental Journey? Some Conceptual Reflections and Empirical Findings". International Perspectives on Higher Education Research. Vol. 3: 29-65.

Prisacariu, I.S. 2007. "The Symbols Role in the Creation of a European Identity" "Alexandru Ioan Cuza" University of Iasi. The Centre for European Studies in Regional Development.

Risse, T. 2004. „European Institutions and Identity Change: What Have We Learned?", in Herrmann, Richard; Risse, Thomas; Brewer, Marilynn (eds) Transnational identities. Becoming European in the EU. Lanham: Rowman \& Littlefield Publishers.

Sauzet, S. Ø. 2008. Youth and the Erasmus Programme. Roskilde, Denmark http://rudar.ruc.dk/bitstream/1800/3656/1/Youth\%20and\%20Erasmus.p $\underline{\mathrm{df}}$ 
Sedláček, L. 2009. Bridging the Gap to the European Identity. 27th March 2009. Heinrich Böll Stiftung Prague http://www.boell.cz/web/52-535.html

Sinnot, R. 2005. „An evaluation of the measurement of national, subnational and supranational identity in crossnational surveys". International Journal of Public Opinion Research, 18 (2): 211-223.

Sigalas, E. 2006. "Remaining proud of their National Identity, Yet Uniting Ever more Closely? The Erasmus Students as the Role Model European citizens". University of Reading, UK http://web.uvic.ca/ecsac/biennial2006/pdf/Emmanuel-Sigalas.pdf

Sigalas, E. 2009. "Does ERASMUS Student Mobility promote a European Identity?" Institute for European Integration Research, Vienna http://www.bath.ac.uk/esml/conWEB/Conweb\%20papersfilestore/conweb\%202 2009.pdf

Smith, A. D. 1992. "National Identity and the Idea of European Unity". International Affairs, 68: 55-76.

Snow, D. 2001. "Collective Identity and Expressive Forms." eScholarship Repository

http://repositories.cdlib.org/cgi/viewcontent.cgi?article $=1016 \&$ context $=$ $\underline{\mathrm{csd}}$

Valentini C. 2005. The promotion of European identity. In: Jaakko Lehtonen and Diana Petkova (eds.) Cultural Identity in an Intercultural context; Jyväskylä University Press, Jyväskylä, Finland, 196-213.

Van Mol, C. 2009a. "The Influence of European Student Mobility on European Identity and subsequent migration aspirations. A Theoretical Framework on European Student Mobility" Working paper No. 1 Universiteit Antwerpen.

http://www.ua.ac.be/main.aspx?c=.ESM\&n=72885

Van Mol, C. 2009b. "The Influence of European Student Mobility on European Identity and Subsequent Migration Intentions" Article for the International Bilingual Conference "Academic Mobility: New Researches and Perspectives", Tallinn University, 24-26 September 2009 http://www.ua.ac.be/main.aspx?c=.ESM\&n=86493

Žagar, M. 2001. Enlargement - in Search for European Identity. University of Ljubljana. $\quad$ http://www.esec.pt/veem/materials/pdf/aditionalReadings/zagareuropean identity.pdf 